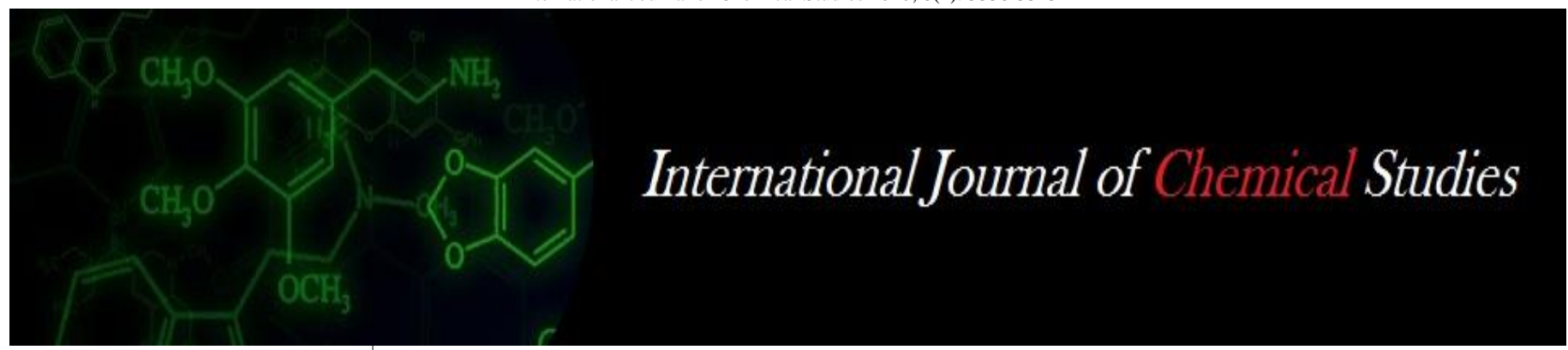

P-ISSN: 2349-8528

E-ISSN: 2321-4902

www.chemijournal.com

IJCS 2020; 8(4): 3338-3343

(C) 2020 IJCS

Received: 07-05-2020

Accepted: 09-06-2020

\section{Singh BRSS}

All India Coordinated Research

Project on Potato, Odisha

University of Agriculture \&

Technology, Bhubaneswar,

Odisha, India

\section{Mishra A}

All India Coordinated Research

Project on Potato, Odisha

University of Agriculture \&

Technology, Bhubaneswar,

Odisha, India

\section{Charanteja B}

All India Coordinated Research

Project on Potato, Odisha

University of Agriculture \&

Technology, Bhubaneswar,

Odisha, India
Corresponding Author: Singh BRSS

All India Coordinated Research

Project on Potato, Odisha

University of Agriculture \&

Technology, Bhubaneswar,

Odisha, India

\section{Genetic variability and character association for some important morphological, physiological and biochemical traits of table potato (Solanum tuberosum L.)}

\author{
Singh BRSS, Mishra A and Charanteja B
}

DOI: $\underline{\text { htps://doi.org/10.22271/chemi.2020.v8.i4ap.10167 }}$

\begin{abstract}
An experiment was carried out at the Research Farm of AICRP on Potato under Odisha University of Agriculture and Technology, Bhubaneswar to study variability and character association among twenty morphologically distinguishable potato genotypes. Data on morphological traits like plant height, shoots/plant, haulm dry matter and leaf chlorophyll content were recorded from five randomly selected plants per plot. A total of 11 morphological and physio-biochemical traits were analyzed for genetic variability, heritability, genetic advance, correlation coefficient and path analysis. Analysis of variance revealed significant differences among the genotypes for all the characters. Out of 20 genotypes under study, Kufri Ganga (24.24 t/ha), AICRP P-22 (22.60 t/ha), AICRP P-7 (19.50 t/ha), Kufri Mohan (18.58 t/ha), Kufri Lima (18.14 t/ha) and AICRP P-31 (18.06 t/ha) were observed to be high yielding. High values of phenotypic coefficient of variation (PCV) and genotypic coefficient of variation (GCV) were observed for reducing sugar content $(41.91,41.75)$ and shoots per plant $(39.60,38.96)$. Highest heritability $(99.17 \%)$ was recorded for reducing sugar content. Traits like reducing sugar content (73.11), shoots per plant (67.44), chlorophyll content (52.39) and plant height (38.76) exhibited high values for genetic advance as percentage of mean. Significant positive correlation of total tuber yield was recorded with reducing sugars both at phenotypic and genotypic levels. Foliage senescence was negatively correlated with tuber dry matter both at phenotypic and genotypic levels. Path analysis revealed that maximum positive and direct effect on total tuber yield was exerted by plant height $(0.509)$, followed by tuber dry matter $(0.385)$, reducing sugars $(0.339)$, haulm dry matter $(0.325)$ and emergence percentage (0.198).
\end{abstract}

Keywords: Table potato, heritability, genetic advance, correlation, path analysis

\section{Introduction}

Potato (Solanum tuberosum L.) is the most important vegetable today and is grown under various agro-ecological conditions of the world. Potato is cultivated in well drained loam to sandy loam soil with a $\mathrm{pH}$ range of 5.2-6.4. It provides high yield even under variable soil and weather conditions (Lisinska and Leszcynski, 1989) ${ }^{[13]}$. This starchy edible tuber is highly palatable and has a rich nutritive value which makes it a highly efficient crop in combating malnutrition (Rytel et al., 2005) ${ }^{[19]}$. India is the second largest producer of potato in the world (FAO STAT, 2017) ${ }^{[8]}$. Potatoes are an inexpensive source of energy and high quality protein (Lachman et al., 2001) ${ }^{[12]}$. In India, potato is grown either under sub-tropical plains or in temperate hill conditions. It is usually propagated through asexual (vegetative) methods although some new potato varieties are being grown from seeds, also called "true potato seed" (shortly, TPS) or "botanical seed" to distinguish it from seed tubers. In India, ICAR-Central Potato Research Institute, Shimla, a premier national institute for research on potato has released many improved varieties of this species which are widely cultivated although few old varieties like Phulwa, Darjeeling Red Round and Gola are still popular at certain locations. Analysis of variation and character association provide information about the response of various characters which is helpful in developing a suitable breeding procedure for improvement in magnitude and nature of variability. Improvement in mean genotypic value of selected plants over the parental population is known as genetic advance. It is the measure of genetic gain under selection. 
Correlation among different characters is utilized in selection of better plant types. Path coefficient analysis further divides correlation into direct and indirect effects leading to the identification of important traits. Path coefficients are standardized partial regression coefficients which individually provide a measure of direct effect of a causal factor on effect variable. A number of approaches like combining ability analysis, use of mid-parent values, progeny tests, estimated breeding values and genetic diversity have been used by plant breeders to select the best parents and cross-combinations (Gopal, 2015) ${ }^{[9]}$. Diversity among genotypes can be assessed through the use of phenotypic information, pedigree, biochemical and molecular markers (Govindaraj et al., 2015) [10]. The major factor limiting the processing quality of potatoes is their rate of reducing sugar production in storage. It is well known that sucrose (12-carbon, non-reducing sugar) is the major free sugar found in immature potatoes. Although sucrose does not participate in the unfavourable nonenzymatic browning of processed products directly, it serves as a substrate for reducing sugar production via the storage activated enzyme invertase. For preparing good quality potato chips, the reducing sugar content should be less than 150 $\mathrm{mg} / 100 \mathrm{~g}$ tuber fresh weight. If the level of reducing sugars is more than this, the fried product becomes dark in colour and unacceptable. The dark colour is formed due to a reaction called 'Maillard reaction' between reducing sugars and free amino acids at high temperatures.

In crop improvement the genetic component of variation is important since this component is transmitted to the next generation. Heritability $\left(h^{2}\right)$ and Additive Variance are fundamental measures of how well quantitative traits are transmitted from one generation to the next. Yield is a character quantitatively inherited (Falconer and Mackay, 1996) ${ }^{[7]}$. It has also been reported that both GCA and SCA are significant for potato yield. This implies that both additive and non-additive gene actions are important for potato tuber yield with non-additive gene action being more predominant. The genetic variance of any quantitative trait is composed of additive variance (which is heritable) and non-additive variance (dominance and epistasis). Therefore, it becomes necessary to divide the observed phenotypic variability into heritable and non-heritable components with parameters such as phenotypic and genotypic coefficient of variation, heritability and genetic advance. Correlation is any statistical association, often refers to how close two variables are to having a linear relationship with each other. There are several correlation coefficients, often denoted as $\rho$ or $r$, measuring the degree of correlation. The most common is the Pearson correlation coefficient, which is sensitive only to a linear relationship between two variables. Yield is a complex character (quantitative character) controlled by a large number of contributing characters and their interactions. A study of correlation between different quantitative characters provides an idea of association that could be effectively exploited to formulate selection strategies for improving yield components.

\section{Materials and Methods}

The experiment was carried out at the research farm of AICRP on Potato under Odisha University of Agriculture and Technology, Bhubaneswar during the rabi season of 2017-18. Twenty test entries received from Central Potato Research Institute, Shimla were evaluated at All India Coordinated Research Project on Potato, Odisha University of Agriculture \& Technology, Bhubaneswar, Odisha. The experiment was laid out in a Randomized Block Design with four replications. The fertilizer dose applied to the crop was $150 \mathrm{~kg} \mathrm{~N} / \mathrm{ha}, 80 \mathrm{~kg}$ $\mathrm{P}_{2} \mathrm{O}_{5} / \mathrm{ha}$ and $100 \mathrm{~kg} \mathrm{~K} 2 \mathrm{O} / \mathrm{ha}$. The spacing was $60 \mathrm{~cm}$ between rows and $20 \mathrm{~cm}$ between plants within a row. Standard agronomic practices were followed to raise the crop. Observations were recorded for 11 characters viz. plant height $(\mathrm{cm})$, emergence $(\%)$, shoots per plant, specific density $\left(\mathrm{g} / \mathrm{cm}^{3}\right)$, tuber dry matter $(\%)$, total tuber yield $(\mathrm{t} / \mathrm{ha})$, haulm dry matter $(\%)$, foliage senescence $(\%)$, tuber rottage $(\mathrm{t} / \mathrm{ha})$, chlorophyll content of leaves (SPAD) and reducing sugar content $(\mathrm{mg} / 100 \mathrm{~g})$. Data on morphological traits like plant height, shoots/plant, haulm dry matter and leaf chlorophyll content were recorded from five randomly selected plants per plot. The critical difference (CD) was used to compare means of different treatments.

A total of 11 morphological and biochemical traits were analyzed for genetic variability, heritability, genetic advance, character association and path analysis. The data recorded for various characters were subjected to statistical analysis based on their sample means (Gomez and Gomez, 1983). Observations of all the 11 characters were analyzed for variability and other genetic parameters related to total tuber yield and were taken for character association studies. The analysis of variance for each of the characters stated was done to find out varietal differences.

The genotypic co-efficient of variation (GCV) and the phenotypic co-efficient of variation (PCV) were calculated using the formula given by Burton (1952).The heritability estimates were used to measure the degree of correspondence between phenotypic value and breeding value. The phenotypic, genotypic and environmental correlations were calculated to determine the pattern and degree of association among the component characters and also to determine their association with grain yield. Both genotypic and phenotypic coefficients of correlation between all pairs of characters were determined by using variance and covariance components. The path coefficients were obtained by solving the equations which give the basic relationship between correlations and path coefficients through the procedure suggested by Dewey and $\mathrm{Lu}(1959)^{[5]}$.

\section{Results and Discussion \\ General performance of the genotypes}

Analysis of variance revealed significant differences among genotypes for all the characters. The coefficient of variation was less for most of the characters indicating good precision of the experiment. Maximum plant height of $60.85 \mathrm{~cm}$ was recorded in Kufri Chipsona-3 (Table 1). The percentage of emergence was the highest $(95.30 \%)$ in AICRP P-12 with a population mean of $89.08 \%$ for this trait showing good plant stand. The maximum tuber yield of $24.24 \mathrm{t} / \mathrm{ha}$ was recorded in Kufri Ganga against the population mean (average of 20 genotypes) of $17.42 \mathrm{t} / \mathrm{ha}$ for this trait. The maximum specific density of $1.13 \mathrm{~g} / \mathrm{cm}^{3}$ was observed in AICRP P-22 while the maximum tuber dry matter content of $22.10 \%$ was found in Kufri Lima. The maximum chlorophyll content (SPAD) value of 34.22 was observed in Kufri Surya with a population mean of 23.36 for this trait. Similarly, the maximum reducing sugars content of $387.25 \mathrm{mg} / 100 \mathrm{~g}$ was recorded in AICRP P29 with a population mean of $203.51 \mathrm{mg} / 100 \mathrm{~g}$ for this trait. Tuber yield of Kufri Ganga (24.24 t/ha) was significantly higher than rest of the genotypes. 


\section{Parameters of genetic variability}

The phenotypic and genotypic variances were the highest (7277.745, 7218.028) for reducing sugar content (Table 2). Highest phenotypic coefficient of variation (PCV) and genotypic coefficient of variation $(\mathrm{GCV})$ were observed for tuber rottage $(96.81,90.59)$. High values of PCV and GCV were observed for reducing sugar content (41.91, 41.75), shoots per plant $(39.60,38.96)$, chlorophyll content $(30.73$, $30.27)$, foliage senescence $(27.78,27.54)$ and plant height (22.30, 22.17). The lowest values of PCV and GCV were recorded for specific density of tubers $(3.77,3.75)$.High PCV and GCV were also reported for number of tubers (Birhman et al., 1988) ${ }^{[2]}$ and number of shoots (Dixit et al., 1994) ${ }^{[6]}$.

The estimates of heritability (broad sense), genetic advance and genetic advance as percentage of mean, presented in Table 2, will be helpful in predicting the gain under selection. The heritability of different characters ranged from 38.06$99.17 \%$. Highest heritability $(99.17 \%)$ was recorded for reducing sugar content. Heritability estimates were high for specific density $(99.11 \%)$, plant height $(98.81 \%)$, foliage senescence $(98.27 \%)$, chlorophyll content $(96.99 \%)$ and shoots per plant $(96.76 \%)$. The least heritable character was found to be emergence percentage $(38.06 \%)$. High heritability was also reported by Dixit et al. (1994) ${ }^{[6]}$ for specific density of tuber.Genetic advance expressed as percentage of mean varied from 4.30 percent for emergence to 113.33 percent for tuber rottage. Traits like reducing sugar (73.11), shoots per plant (67.44), chlorophyll content (52.39) exhibited high values of genetic advance as percentage of mean. Traits like emergence percentage (4.30) and specific density (5.14) exhibited low values for genetic advance as percentage of mean.

The characters like tuber rottage, reducing sugars, shoots per plant, chlorophyll content, foliage senescence and plant height exhibited high GCV coupled with high heritability and high genetic gain. Similar results were recorded by Patel et al. (2013) ${ }^{[17]}$. Trait like emergence percentage exhibited low GCV with low heritability and thus low genetic gain.

\section{Correlation coefficient analysis}

In the present investigation, the genotypic correlation coefficients in general were higher than the phenotypic correlation coefficients. The total tuber yield was positively correlated with reducing sugar content both at phenotypic and genotypic level (Table 3). Correlation among component traits showed that foliage senescence was negatively correlated with tuber rottage, tuber dry matter and chlorophyll content both at phenotypic and genotypic level. Tuber dry matter was positively correlated with haulm dry matter, shoots per plant and chlorophyll content both at phenotypic and genotypic level. Improvement in the characters which have highly significant and positive correlation with the total tuber yield will directly or indirectly lead to increase in tuber yield which has been reported with plant height (Zakaria et al., 2007 and Sandhu and Kang, 1998) [22, 20] and number of shoots per plant (Zakaria et al., 2007) ${ }^{[22]}$.

\section{Path coefficient analysis \\ Genotypic path coefficient}

Maximum positive and direct effect on total tuber yield was exerted by specific density (0.755) followed by plant height (0.509), tuber dry matter (0.385), reducing sugars (0.339), haulm dry matter $(0.325)$ and emergence percentage $(0.198)$ while SPAD chlorophyll content (-0.465) exhibited highest negative and direct effect on total tuber yield followed by shoots per plant (-0.347), tuber rottage (-0.330) and foliage senescence (-0.197). Traits like specific density imposed high positive and indirect effect through shoots per plant (0.304), specific density through tuber dry matter (0.271), specific density through tuber rottage (0.263) and chlorophyll content through foliage senescence $(0.2558)$. Traits like specific density imposed high negative and indirect effect through plant height (-0.452). The residual effect at genotypic level was observed to be 0.555 .

\section{Phenotypic path coefficient}

Maximum positive and direct effect on total tuber yield was exerted by specific density (0.554) followed by reducing sugars $(0.382)$, plant height $(0.265)$, haulm dry matter $(0.179)$ and emergence percentage $(0.108)$ while foliage senescence (0.418 ) exhibited highest negative and direct effect on total tuber yield followed by tuber rottage $(-0.137)$. Traits like foliage senescence imposed high positive and indirect effect through tuber dry matter $(0.325)$, foliage senescence through tuber rottage (0.236), foliage senescence through chlorophyll content (0.231), chlorophyll content through foliage senescence $(0.223)$ and specific density through shoots per plant (0.222). Desai and Jaimini (1998) ${ }^{[4]}$ reported positive direct effect of plant height and shoot per plant on tuber yield. Kumar and Kang (2000) [11] found similar kind of observations. Plant height is one of the most important components for total tuber yield in potato (Khayatnezhad et al., 2011). The residual effect at phenotypic level was found to be 0.575 .

Table 1: Performance of 20 potato genotypes with respect to various morphological, physiological and biochemical characters.

\begin{tabular}{|c|c|c|c|c|c|c|c|c|c|c|c|}
\hline Genotypes & $\begin{array}{c}\text { Emergence } \\
(\%)\end{array}$ & $\begin{array}{c}\text { Foliage } \\
\text { senescence } \\
(\%)\end{array}$ & $\begin{array}{c}\text { Tuber } \\
\text { rottage } \\
\text { (t/ha) }\end{array}$ & $\begin{array}{c}\text { Tuber } \\
\text { dry } \\
\text { matter } \\
(\%)\end{array}$ & $\begin{array}{c}\text { Haulm } \\
\text { dry } \\
\text { matter } \\
(\%)\end{array}$ & $\begin{array}{l}\text { Plant } \\
\text { height } \\
(\mathbf{c m})\end{array}$ & $\begin{array}{l}\text { Shoots } \\
\text { per } \\
\text { plant }\end{array}$ & $\begin{array}{c}\text { Chlorophyll } \\
\text { content } \\
\text { (SPAD) }\end{array}$ & $\begin{array}{l}\text { Specific } \\
\text { density } \\
\left(\mathrm{g} / \mathrm{cm}^{3}\right)\end{array}$ & $\begin{array}{c}\text { Reducing } \\
\text { sugars } \\
(\mathrm{mg} / \mathbf{1 0 0 g})\end{array}$ & $\begin{array}{l}\text { Total } \\
\text { tuber } \\
\text { yield } \\
\text { (t/ha) }\end{array}$ \\
\hline AICRP-P-7 & 89.27 & 58.25 & 0.39 & 18.99 & 8.93 & 39.05 & 3.20 & 29.70 & 1.07 & 192.25 & 19.50 \\
\hline AICRP-P-12 & 95.30 & 57.50 & 0.14 & 17.01 & 6.20 & 35.03 & 4.43 & 33.14 & 1.08 & 236.25 & 13.85 \\
\hline AICRP-P-24 & 93.15 & 74.25 & 0.50 & 15.77 & 5.88 & 50.47 & 4.05 & 30.94 & 1.09 & 136.50 & 14.64 \\
\hline AICRP-P-22 & 89.62 & 80.50 & 0.46 & 17.27 & 7.15 & 28.52 & 3.05 & 17.65 & 1.13 & 223.00 & 22.60 \\
\hline K Ganga & 92.88 & 81.00 & 1.68 & 16.83 & 8.00 & 46.70 & 4.35 & 13.70 & 1.12 & 385.75 & 24.24 \\
\hline K Khyati & 88.75 & 72.25 & 0.72 & 16.26 & 8.00 & 52.22 & 4.80 & 20.44 & 1.05 & 97.50 & 15.10 \\
\hline K Pukhraj & 89.78 & 89.50 & 0.90 & 15.85 & 7.10 & 29.92 & 2.57 & 16.76 & 1.11 & 124.25 & 15.75 \\
\hline K Ashoka & 88.05 & 86.50 & 0.43 & 16.82 & 7.75 & 44.30 & 2.42 & 12.08 & 1.03 & 259.00 & 17.26 \\
\hline K Jyoti & 93.77 & 84.50 & 0.19 & 16.15 & 7.03 & 36.23 & 3.18 & 13.74 & 1.05 & 145.50 & 14.75 \\
\hline K Lalima & 90.05 & 68.50 & 1.24 & 16.07 & 6.22 & 44.88 & 2.40 & 31.35 & 1.04 & 176.50 & 16.19 \\
\hline K Chipsona-3 & 80.75 & 38.75 & 0.96 & 20.88 & 7.20 & 60.85 & 5.45 & 29.87 & 1.06 & 66.50 & 16.56 \\
\hline K Mohan & 78.47 & 61.50 & 0.47 & 16.41 & 8.00 & 37.50 & 3.25 & 22.55 & 1.10 & 208.75 & 18.58 \\
\hline
\end{tabular}




\begin{tabular}{|c|c|c|c|c|c|c|c|c|c|c|c|}
\hline K Lalit & 87.70 & 66.50 & 0.25 & 17.32 & 7.00 & 46.35 & 2.75 & 27.67 & 1.08 & 259.25 & 17.26 \\
\hline K Chipsona-1 & 89.05 & 61.25 & 0.78 & 19.02 & 7.13 & 44.63 & 5.45 & 24.59 & 1.05 & 107.00 & 17.08 \\
\hline AICRP-P-29 & 83.73 & 82.00 & 1.56 & 16.55 & 7.68 & 52.30 & 2.00 & 23.81 & 1.04 & 387.25 & 16.01 \\
\hline AICRP-P-31 & 87.07 & 68.50 & 0.81 & 16.36 & 7.05 & 48.40 & 2.22 & 21.78 & 1.03 & 269.75 & 18.06 \\
\hline AICRP-P-36 & 90.38 & 68.50 & 0.46 & 15.09 & 7.91 & 44.68 & 1.83 & 15.20 & 1.02 & 161.75 & 17.90 \\
\hline K Pushkar & 92.90 & 71.50 & 0.46 & 15.75 & 7.64 & 42.75 & 2.13 & 18.95 & 1.04 & 228.25 & 17.92 \\
\hline K Lima & 91.60 & 6.75 & 3.69 & 22.10 & 8.80 & 24.52 & 2.70 & 29.04 & 1.11 & 173.25 & 18.14 \\
\hline K Surya & 89.40 & 68.50 & 2.01 & 19.83 & 9.25 & 29.52 & 6.65 & 34.22 & 1.12 & 232.00 & 17.03 \\
\hline Grand mean & 89.08 & 67.32 & 0.90 & 17.32 & 7.50 & 41.94 & 3.44 & 23.36 & 1.07 & 203.51 & 17.42 \\
\hline SE $( \pm m)$ & 3.19 & 1.74 & 0.16 & 0.31 & 0.22 & 0.72 & 0.17 & 0.88 & 0.02 & 5.46 & 0.41 \\
\hline CD $(0.05)$ & 6.38 & 3.47 & 0.31 & 0.63 & 0.43 & 1.44 & 0.35 & 1.76 & 0.04 & 10.93 & 0.82 \\
\hline CV $(\%)$ & 5.06 & 3.65 & 24.60 & 2.57 & 4.07 & 2.42 & 7.12 & 5.33 & 2.96 & 3.80 & 3.31 \\
\hline
\end{tabular}

Table 2: Range, variance, genotypic and phenotypic coefficient of variation, heritability and genetic advance estimates for eleven characters under study.

\begin{tabular}{|c|c|c|c|c|c|c|c|c|c|}
\hline \multirow{2}{*}{$\begin{array}{l}\text { Sl. } \\
\text { No. }\end{array}$} & \multirow{2}{*}{ Characters } & \multirow{2}{*}{ Range } & \multicolumn{2}{|c|}{ Variance } & \multicolumn{2}{|c|}{ Coefficient of variation (\%) } & \multirow{2}{*}{$\begin{array}{c}\text { Heritability } \\
(\%)\end{array}$} & \multirow{2}{*}{\begin{tabular}{|c|}
$\begin{array}{c}\text { Genetic } \\
\text { advance }\end{array}$ \\
\end{tabular}} & \multirow{2}{*}{$\begin{array}{l}\text { Genetic advance } \\
\text { as \% of mean } \\
\text { (genetic gain) }\end{array}$} \\
\hline & & & Genotypic & Phenotypic & GCV & PCV & & & \\
\hline 1 & Emergence $(\%)$ & $78.47-95.30$ & 12.487 & 32.808 & 3.97 & 6.43 & 38.063 & 3.83 & 4.30 \\
\hline 2 & Foliage senescence (\%) & $6.75-89.50$ & 343.849 & 349.874 & 27.54 & 27.78 & 98.278 & 32.33 & 48.02 \\
\hline 3 & Tuber rottage $(\mathrm{t} / \mathrm{ha})$ & $0.10-2.66$ & 0.348 & 0.397 & 90.59 & 96.81 & 87.558 & 1.02 & 113.33 \\
\hline 4 & Tuber dry matter $\%$ & $15.09-22.10$ & 3.450 & 3.648 & 10.73 & 11.03 & 94.573 & 3.17 & 18.30 \\
\hline 5 & Haulm dry matter $\%$ & $5.88-9.25$ & 0.763 & 0.883 & 11.65 & 12.36 & 89.156 & 1.47 & 19.60 \\
\hline 6 & Plant height $(\mathrm{cm})$ & $24.52-60.85$ & 86.435 & 87.468 & 22.17 & 22.30 & 98.819 & 16.26 & 38.76 \\
\hline 7 & Shoots per plant & $1.83-6.65$ & 1.800 & 1.860 & 38.96 & 39.60 & 96.762 & 2.32 & 67.44 \\
\hline 8 & $\begin{array}{l}\text { Chlorophyll content } \\
\text { (SPAD) }\end{array}$ & $12.08-34.22$ & 49.996 & 51.544 & 30.27 & 30.73 & 96.995 & 12.24 & 52.39 \\
\hline 9 & Specific density $\left(\mathrm{g} / \mathrm{cm}^{3}\right)$ & $1.02-1.13$ & 0.001 & 0.001 & 3.75 & 3.77 & 99.118 & 0.055 & 5.14 \\
\hline 10 & Reducing sugars $(\mathrm{mg} / 100 \mathrm{~g})$ & 66.50-387.25 & 7218.028 & 7277.745 & 41.75 & 41.91 & 99.179 & 148.79 & 73.11 \\
\hline 11 & Total tuber yield (t/ha) & $13.85-24.24$ & 3.213 & 3.546 & 14.29 & 15.01 & 90.603 & 3.00 & 17.22 \\
\hline
\end{tabular}

$\mathrm{GCV}$ - genotypic coefficient of variation, PCV- phenotypic coefficient of variation

Table 3: Estimates of phenotypic and genotypic correlation coefficients among eleven characters in potato

\begin{tabular}{|c|c|c|c|c|c|c|c|c|c|c|c|c|}
\hline Sl. No. & Characters & & FS & TR & TDM & HDM & PH & SPP & SPAD & SD & RS & TTY \\
\hline \multirow{2}{*}{1} & \multirow{2}{*}{ EP } & $\mathrm{r}_{\mathrm{ph}}$ & 0.125 & 0.010 & -0.178 & -0.200 & -0.354 & -0.020 & -0.065 & 0.109 & 0.018 & -0.064 \\
\hline & & $r_{g}$ & 0.139 & 0.025 & -0.214 & -0.250 & -0.426 & -0.029 & -0.076 & 0.125 & 0.029 & -0.047 \\
\hline \multirow{2}{*}{2} & \multirow{2}{*}{ FS } & $\mathrm{r}_{\mathrm{ph}}$ & & $-0.565 * *$ & $-0.779 * *$ & -0.273 & 0.136 & -0.174 & $-0.554 *$ & -0.148 & 0.298 & 0.020 \\
\hline & & $r_{g}$ & & $-0.578 * *$ & $-0.788 * *$ & -0.277 & 0.137 & -0.177 & $-0.556^{*}$ & -0.149 & 0.299 & 0.021 \\
\hline \multirow{2}{*}{3} & \multirow{2}{*}{ TR } & $\mathrm{r}_{\mathrm{ph}}$ & & & $0.618 * *$ & $0.483 *$ & -0.292 & 0.115 & 0.251 & 0.340 & 0.148 & 0.188 \\
\hline & & $r_{g}$ & & & $0.633^{* *}$ & $0.505^{*}$ & 0.297 & 0.118 & 0.256 & 0.348 & 0.151 & 0.193 \\
\hline \multirow{2}{*}{4} & \multirow{2}{*}{ TDM } & $\mathrm{r}_{\mathrm{ph}}$ & & & & $0.467 *$ & 0.209 & $0.482 *$ & $0.504 *$ & 0.356 & 0.197 & 0.127 \\
\hline & & $r_{g}$ & & & & $0.483^{*}$ & -0.209 & $0.486^{*}$ & $0.511 *$ & 0.359 & -0.199 & 0.134 \\
\hline \multirow{2}{*}{5} & \multirow{2}{*}{ HDM } & $\mathrm{r}_{\mathrm{ph}}$ & & & & & -0.303 & 0.140 & -0.067 & 0.225 & 0.168 & 0.402 \\
\hline & & $r_{g}$ & & & & & -0.308 & 0.142 & -0.069 & 0.232 & 0.171 & 0.413 \\
\hline \multirow{2}{*}{6} & \multirow{2}{*}{$\mathrm{PH}$} & $\mathrm{r}_{\mathrm{ph}}$ & & & & & & 0.063 & -0.004 & $-0.596 * *$ & -0.009 & -0.166 \\
\hline & & $r_{g}$ & & & & & & 0.063 & -0.003 & $-0.599 * *$ & -0.008 & -0.168 \\
\hline \multirow{2}{*}{7} & \multirow{2}{*}{ SPP } & $\mathrm{r}_{\mathrm{ph}}$ & & & & & & & 0.425 & 0.400 & -0.295 & -0.087 \\
\hline & & $r_{g}$ & & & & & & & 0.428 & 0.403 & -0.296 & -0.088 \\
\hline \multirow{2}{*}{8} & \multirow{2}{*}{ SPAD } & $\mathrm{r}_{\mathrm{ph}}$ & & & & & & & & 0.203 & -0.175 & -0.348 \\
\hline & & $\mathrm{rg}_{\mathrm{g}}$ & & & & & & & & 0.204 & -0.176 & -0.354 \\
\hline \multirow{2}{*}{9} & \multirow{2}{*}{ SD } & $\mathrm{r}_{\mathrm{ph}}$ & & & & & & & & & 0.074 & 0.393 \\
\hline & & $r_{g}$ & & & & & & & & & 0.074 & 0.400 \\
\hline \multirow{2}{*}{10} & \multirow{2}{*}{$\mathrm{RS}$} & $\mathrm{r}_{\mathrm{ph}}$ & & & & & & & & & & $0.452 *$ \\
\hline & & $r_{g}$ & & & & & & & & & & $0.457^{*}$ \\
\hline
\end{tabular}

* and ** Significant at 5\% and $1 \%$ level of probability respectively

Table 4: Path co-efficient analysis of direct (diagonal) and indirect effects of various traits on total tuber yield

\begin{tabular}{|c|c|c|c|c|c|c|c|c|c|c|c|c|c|}
\hline Sl. No. & Characters & & EP & FS & TR & TDM & HDM & PH & SPP & SPAD & SD & RS & Correlation with TTY \\
\hline \multirow{2}{*}{1} & \multirow{2}{*}{ EP } & Phenotypic & 0.108 & -0.052 & -0.001 & 0.001 & -0.036 & 0.094 & 0.002 & 0.026 & 0.060 & 0.007 & -0.064 \\
\cline { 3 - 12 } & & Genotypic & 0.198 & -0.027 & -0.008 & -0.082 & -0.081 & -0.217 & 0.010 & 0.035 & 0.094 & 0.010 & -0.047 \\
\hline \multirow{2}{*}{2} & \multirow{2}{*}{ FS } & Phenotypic & -0.013 & -0.418 & 0.077 & 0.005 & -0.049 & 0.036 & 0.020 & 0.223 & -0.082 & 0.114 & 0.020 \\
\cline { 3 - 12 } & & Genotypic & 0.028 & -0.197 & 0.191 & -0.303 & -0.090 & 0.070 & 0.061 & 0.258 & -0.112 & 0.101 & 0.021 \\
\multirow{2}{*}{3} & \multirow{2}{*}{ TR } & Phenotypic & -0.001 & 0.236 & -0.137 & -0.004 & 0.086 & -0.077 & -0.013 & -0.101 & 0.188 & 0.057 & 0.188 \\
\cline { 3 - 12 } & & Genotypic & 0.005 & 0.114 & -0.330 & 0.244 & 0.164 & -0.151 & -0.041 & -0.119 & 0.263 & 0.051 & 0.193 \\
\hline \multirow{2}{*}{4} & \multirow{2}{*}{ TDM } & Phenotypic & 0.019 & 0.325 & -0.085 & -0.006 & 0.083 & -0.055 & -0.055 & -0.203 & 0.197 & -0.075 & \\
\cline { 3 - 11 } & & Genotypic & -0.042 & 0.155 & -0.209 & 0.385 & 0.157 & -0.106 & -0.169 & -0.237 & 0.271 & -0.067 & 0.127 \\
\hline 5 & \multirow{2}{*}{ HDM } & Phenotypic & 0.022 & 0.114 & -0.066 & -0.003 & 0.179 & -0.080 & -0.016 & 0.027 & 0.125 & 0.064 & \\
0
\end{tabular}




\begin{tabular}{|c|c|c|c|c|c|c|c|c|c|c|c|c|c|}
\hline & & Genotypic & -0.050 & 0.055 & -0.167 & 0.186 & 0.325 & -0.157 & -0.049 & 0.032 & 0.175 & 0.058 & 0.413 \\
\hline \multirow{2}{*}{6} & \multirow{2}{*}{ PH } & Phenotypic & 0.038 & -0.057 & 0.040 & 0.001 & -0.054 & 0.265 & -0.007 & 0.002 & -0.330 & -0.003 & -0.166 \\
\hline & & Genotypic & -0.084 & -0.027 & 0.098 & -0.080 & -0.100 & 0.509 & -0.022 & 0.001 & -0.452 & -0.003 & -0.168 \\
\hline \multirow{2}{*}{7} & \multirow{2}{*}{ SPP } & Phenotypic & 0.002 & 0.073 & -0.016 & -0.003 & 0.025 & 0.017 & -0.114 & -0.171 & 0.222 & -0.113 & -0.087 \\
\hline & & Genotypic & -0.006 & 0.035 & -0.039 & 0.187 & 0.046 & 0.032 & -0.347 & -0.199 & 0.304 & -0.100 & -0.088 \\
\hline \multirow{2}{*}{8} & \multirow{2}{*}{ SPAD } & Phenotypic & 0.007 & 0.231 & -0.034 & -0.003 & -0.012 & -0.001 & -0.048 & -0.403 & 0.112 & -0.067 & -0.348 \\
\hline & & Genotypic & -0.015 & 0.109 & -0.084 & 0.197 & -0.022 & -0.002 & -0.149 & -0.465 & 0.154 & -0.060 & -0.354 \\
\hline \multirow{2}{*}{9} & \multirow{2}{*}{ SD } & Phenotypic & -0.012 & 0.062 & -0.047 & -0.002 & 0.040 & -0.158 & -0.046 & -0.082 & 0.554 & 0.028 & 0.393 \\
\hline & & Genotypic & 0.025 & 0.029 & -0.115 & 0.138 & 0.075 & -0.305 & -0.140 & -0.095 & 0.755 & 0.025 & 0.400 \\
\hline \multirow{2}{*}{10} & \multirow{2}{*}{ RS } & Phenotypic & -0.002 & -0.124 & -0.020 & 0.001 & 0.030 & -0.002 & 0.034 & 0.071 & 0.041 & 0.382 & 0.452 \\
\hline & & Genotypic & 0.006 & -0.059 & -0.050 & -0.077 & 0.056 & -0.004 & \begin{tabular}{|l|}
0.103 \\
\end{tabular} & 0.082 & 0.056 & 0.339 & 0.457 \\
\hline
\end{tabular}

Residual effect: 0.575 (Phenotypic Path) Residual effect: 0.555 (Genotypic path)

EP-Emergence percentage (\%). FS-Foliage senescence (\%), TR-Tuber rottage (t/ha), TDM-Tuber dry matter (\%), HDM-Haulm dry matter (\%), PH-Plant height (cm), SSP-Shoots per plant, SPAD-chlorophyll content (SPAD), SD-Specific density (g/cm $\left.{ }^{3}\right), \mathbf{R S}-$ Reducing sugars (mg/100g), TTY-Total tuber yield (t/ha).

\section{Conclusion}

Based on the findings in the present investigation, it can be concluded that significant variation exists among the genotypes based on morphological characters. As per the analysis of variance for different characters, the mean square values due to genotype were highly significant $(p<0.01)$ for all characters studied indicating the existence of sufficient genetic variability. The coefficient of variation was less in all of the characters indicating good precision of the experiment. The genotypes namely Kufri Ganga (24.24 t/ha), AICRP P-22 (22.60 t/ha), AICRP P-7 (19.50 t/ha), Kufri Mohan (18.58 t/ha), Kufri Lima (18.14 t/ha) and AICRP P-31 (18.06 t/ha) were found to be better yielding. Higher values of PCV and GCV were observed for reducing sugar content (41.79, 41.75), shoots per plant $(39.12,38.96)$, chlorophyll content (30.39, 30.27), foliage senescence $(27.60,27.54)$ and plant height $(22.20,22.17)$. Highest heritability $(99.17 \%)$ was recorded for reducing sugar content. Traits like reducing sugars content (73.40), shoots per plant (68.29), chlorophyll content (53.07), plant height (38.96), total tuber yield (34.83) and haulm dry matter (20.20) exhibited high values for genetic advance as percentage of mean. Correlation studies revealed that total tuber yield was positively correlated with reducing sugars content both at phenotypic and genotypic level. Foliage senescence was negatively correlated with tuber dry matter and chlorophyll content both at phenotypic and genotypic level. High positive and direct effect on total tuber yield was exerted by specific density (0.755) and plant height (0.509). Negative and direct effect on total tuber yield was exerted by foliage senescence $(-0.197)$.

\section{References}

1. Birhman RK, Kaul MLH, Sharma HC. Phenotypic and biochemical diversity in Andegena potatoes, Journal of the Indian potatoes Association, 1988; 15: 115-130.

2. Birhman RK, Verrna SM, Anand SK. Phenotypic and genotypic variation for some important quantitative characters in potato (Solanum tuberosum L.), Indian Journal of Agricultural Research. 1984; 18: 137-142.

3. Bradshaw JE and Mackay GR. Breeding strategies for clonally propagated potatoes, Potato genetics, CAB International, Wallingford, 1994.

4. Desai NC, Jaimini SN. Correlation and path analysis of some economic characters in potato, Journal of the Indian Potato Association. 1998; 25(1\&2):25-29.

5. Dewey DR, Lu KH. A correlation and path-coefficient analysis of components of crested wheatgrass seed production, Agronomy Journal. 1959; 51:515-518.

6. Dixit D, Mital RK, Choubey CN, Singh P. Variability, correlation and selection indices in potato (Solarium tuberosum L.), Haryana Journal of Horticultural Science. 1994; 23:168-172.

7. Falconer DS, Mackay TFC. Introduction to quantitative genetics, $4^{\text {th }}$ edition. Prentice Hall, Harlow, 1996.

8. FAO (Food and Agricultural Organisation). FAOSTAT. Food and Agricultural Organisation, Rome, Italy, 2017.

9. Gopal J. In vitro and in vivo genetic parameters and character associations in potato, Euphytica. 2001; 118:145-151.

10. Govindaraj M, Vetriventhan M, Srinivasan M. Importance of genetic diversity assessment in crop plants and its recent advances: An overview of its analytical perspectives. Genet Res International, 2015, 431-487.

11. Kumar R, Kang GS. Genetic diversity among andigena potatoes, Journal of the Indian Potato Association, 1998; 25(1\&2):21-24.

12. Lachman J, Hamouz K, Orsak M, Pivec V. Potato glycoalkaloids and their significance in plant protection and nutrition, Rostlinna Vyroba. 2001; 47:181-191.

13. Lisinska G, Leszcynski W. Potato science and technology, Elsevier, 1989.

14. Luthra SK. Heritability, genetic advance and character association in potato, Journal of the Indian Potato Association. 2001; 28:1-3.

15. Mahalanobis PC. On the generalized distance in statistic, Proceedings of the National Institute of Sciences. 1936; 12: 49-55.

16. Ortiz R, Golmirzaie A. Hierarchical and factorial mating designs for quantitative genetic analysis in tetrasomic potato, Theoretical and Applied Genetics. 2002; 104:675679.

17. Patel CJ, Patel NH, Gami RA, Patel AK, Chauhan RM. Assessment of potato (Solanum tuberosum L.) hybridsvarieties for processing purpose among yield and quality traits, Trends in Biosciences. 2013; 6(5):676-681.

18. Pushkarnath. Potato in India; varieties. Indian Council of Agricultural Research, New Delhi, 1969, 460.

19. Rytel E, Golubowska G, Lisińska G, Pęksa A, Aniolowski K. Changes in glycoalkaloid and nitrate contents in potatoes during french fries processing, Journal of the Science of Food Agriculture. 2005; 85:879-882.

20. Sandhu SK, Kang GS. Genetic analysis in germplsam of andigena potatoes (Solanum tuberosum ssp. andigena), Crop Improvement. 1998; 25:181-185.

21. Tripura A, Das A, Das B, Priya B, Sarkar KK. Genetic studies of variability, character association and path analysis of yield and its component traits in potato (Solanum tuberosum L.), Journal of Crop and Weed, 2016; 12(1):56-63. 
22. Zakaria RA, Fathi M, Panah DH. Sequential path analysis of yield components in potato, Potato Research. 2007; 49(4):273-279. 